\title{
Comprehensive personal witness: a model to enlarge missional involvement of the local church
}

\section{Frans Hancke \& Pieter Verster ${ }^{1}$}

\begin{abstract}
In the The Split-Level Fellowship, Wesley Baker analysed the role of individual members in the Church. He gave a name to a tragic phenomenon with which Church leaders are familiar. Although true of society in general it is especially true of the church. Baker called the difference between the committed few and the uninvolved many, Factor Beta. This reality triggers the question: Why are the majority of Christians in the world not missionally involved through personal witness and which factors consequently influence personal witness and missional involvement? This article explains how the range of personal witness and missional involvement found in local churches are rooted in certain fundamental factors and conditions which are mutually influencing each other and ultimately contribute towards forming a certain paradigm. This paradigm acts as the basis from which certain behavioural patterns (witness) will manifest. The factors influencing witness are either described as accelerators or decelerators and their relativity and mutual relationships are considered. Factors acting as decelerators can severely hamper or even annul witness, while accelerators on the other hand, can have an immensely positive effect to enlarge the transformational influence of witness. In conclusion a transformational model is developed through which paradigms can be influenced and eventually changed. This model fulfils a diagnostic and remedial function and will support local churches to enlarge the individual and corporate missional involvement of believers.
\end{abstract}

\section{Introduction}

In the The Split-Level Fellowship, published in the mid-1960s, Wesley Baker analysed the role of individual members in the Church. He gave a name to a tragic phenomenon with which Church leaders are familiar. He called the difference between the committed few and the uninvolved many, "Factor Beta" (in Van Engen 1991:150). Van Engen describes Factor Beta as "the simple, plain fact that within the recognized corpus of the Church there are two quite different kinds of people - or at least two different sets of motive patterns." He goes on to describe today's typical parish as "made up, usually, of a small inner core of believers who assume the necessary posts of leadership with gratitude and devotion (albeit frequently naive)," surrounded by a "cloud of uninvolved and mildly approving witnesses" (1991:150).

Hancke $(2001: 81,84)$ determined that the existence of Factor Beta is a hindering and demotivating reality in most Churches today. Church leaders

1 Dr F Hancke is a Research Fellow, Department of Missiology, UFS and Prof Pieter Verster, Head Department of Missiology, UFS. 
were positive to discuss ways and means to mobilise the Church towards becoming a missional Church but frequently the reality of Factor Beta casts a shadow over every effort to become the Church-on-mission. As long as only a small minority of believers accept and understand the responsibility to be living witnesses for the living Lord, the impact of Christianity in the world will be marginal.

Against this background the fundamental question lingers: Why are the majority of Christians in the world not missionally involved through personal witness and witnessing lifestyles?

\section{Addressing Factor Beta}

This study is based on the thesis that the range of personal witness and missional involvement found in local Churches are triggered and influenced by certain underlying factors and conditions. These factors and conditions lead to paradigms, which influence behaviour, in this case, the missional involvement of the believer.

To comprehend Factor Beta, it is necessary to acquire enough knowledge and understanding of the factors, conditions and the resulting paradigms which influence the missional involvement (or lack thereof) of believers. From this insight a model can be developed through which these paradigms can be influenced and eventually changed. Because of the causal relationships, such a transformational model can contribute towards a change in behaviour (witness).

In reality the abovementioned factors and conditions influence the effect of Christian witness on society and will either have a positive or negative effect on the outcome of witness. These factors are divided into accelerators or decelerators. If these factors are acting as decelerators, witness can be severely hampered or even annulled. Accelerators on the other hand, can have an immensely positive effect to enlarge the transformational influence of witness. The identification and significance of these factors and conditions create new insight, which can be used strategically to mobilise the whole Church towards taking the whole gospel to the whole world. In this article the essence of comprehensive witness will be assessed.

\section{Towards a comprehensive understanding of witness}

The title of this article clearly states that the research was focussed on comprehensive, personal witness. The expression 'comprehensive' has significant implications for our approach towards the concept of witness. Without such a firm declaration of intention it would have been only possible to study part of the concept or to dilute its Biblical meaning to merely verbal testimony. 
When researching a Biblical concept with a comprehensive approach it can also pose a threat. Stephen Neill wrote in his book, Creative Tension (1959), if everything is mission, then nothing is mission. In a certain sense this is valid for the concept of witness when it is defined so widely that it becomes increasingly difficult to say what witness is. In an interview by the author (Hancke) with Prof Dons Kritzinger (2005), he also warned that it could be risky to open up the concept so extensively that everything will fit the definition. Another danger of widening the scope and content of witness can be that it happens to the expense of the depth of the missio Dei. On the other hand, it would be equally dangerous to narrow it down to the extent where it loses its broad Biblical meaning.

Although comprehensive in our approach, witness in this article is defined as God's people (the Church) who individually and corporately witness intentionally according to the holistic, Biblical view of marturia because the fullness of witness is comprehensively included in the term marturia.

Some scholars stress the fact that "witnessing was inseparably related to suffering for the Christian martus. The reason for this view is partly due to the fact that the English word "martyr" comes from the Greek word martys. The fact that the early New Testament Church experienced a "close relation" between the concepts of witnessing and suffering as martyrs also contributed to this interpretation (Trites 1977:1).

Casey points out that 'the transition from 'witness' to 'martyr' represents only one development of meaning, and that several others of interest exist in the history of early Christian thought. All of these developments begin with a metaphorical application of the legal term, but all do not converge at the point where martus clearly and unmistakably signifies a witness who died for Christianity" (in Trites 1977:2).

Historically it is evident that a broader or more holistic understanding of mission was significantly influenced by insights about the Trinity, the church, the world and society. This missiological development primarily picked up momentum since the middle of the previous century. The expanding paradigm of mission and witness included "a more holistic understanding of God's work in the world in sending his Son" (Van Gelder et al. 2011:28) and a "change from a more anthropocentric understanding of mission to a more theocentric, and from a more ecclesiocentric perspective to a more cosmocentric" (Engelsviken).

The Willingen conference (1952) contributed significantly to this broadening perspective as Karl Hartenstein's report from the conference confirms:

"Mission is not just the conversion of the individual, nor just obedience to the word of the Lord, nor just the obligation to gather the church. It is the taking part in the sending of the Son, the missio 
Dei, with the holistic aim of establishing Christ's rule over all redeemed creation" (in Engelsviken).

This deeper meaning and significance of the missio Dei became clearer as Barth "reclaimed the classical meaning of 'mission' within the interrelations of God as that of sending - the Father sent the Son, and the Father and the Son sent the Spirit" (Van Gelder et al. 2011:26).

This developing paradigm obviously includes a reconsideration of marturia (witness), kerygma (proclamation), koinonia (fellowship) and diakonia (service). The interrelationship between these concepts becomes clearer as Scripture is read "through the lens of a missional hermeneutic" (Van Gelder et al. 2011:45). This missional hermeneutic also sheds more light on our attempt to develop a Biblically sound, holistic understanding and approach to witness, irrespective of the corporate or personal context. Hoekendijk reflects on witness (and evangelism) by identifying its aim as "nothing less than what Israel expected the Messiah to do, i.e. establish shalom". Shalom should be "proclaimed (kerygma), lived in koinonia and demonstrated in humble service, diakonia" (in Engelsviken).

The holistic approach prevents us from dissecting marturia, kerygma, koinonia and diakonia from each other. It rather urges God's people to embrace the full extent of the missio Dei and to respond to his invitation to take part in his 'sending' through witness, proclamation, fellowship and service. Through their partaking in a balanced and all-encompassing manner, the missional Church emerges. (Van Engen 1991:89). Such an understanding of the Church's involvement in God's work does not allow for identifying any one aspect as the primary task of the Church. It is against this background that Sider writes:

"The time has come for all biblical Christians to refuse to use the sentence:

The primary task of the Church is... I do not care if you complete the sentence with evangelism or social action. Either way it is unbiblical and misleading. Both dimensions are indissolubly bound together. If you lose the one, you lose the other" (in Bosch 1980:228).

Van Engen (1991:89) helps us to grasp the deeper meaning of these "aspects of the Church's reason-for-being" by coupling each word to a Biblical statement:

- Koinonia - "Love one another" (Jn 13:34-35; Rm 13:8; 1 Pt 1:22

- Kerygma - "Jesus Is Lord" (Rm 10:9; 1 Cor 12:3)

- Diakonia - "The least of these my brethren" (Mt 25:30,45)

- Marturia - "You shall be my witnesses; be reconciled to God" (Is 43:10,12; 44:8; Ac 1:8; 2 Cor 5:20)

The intimate relationship and inseparability between these aspects comes to the fore as God's people partake in His mission. Through this perspective it becomes clear that "koinonia as a fellowship of love is also the foundation for diakonia, kerygma and marturia". At the same time the "absence of 
diakonia, kerygma or marturia may mean that the Church has turned inward upon itself to such an extent that there is no longer the kind of koinonia of which Jesus spoke" (Van Engen 1991:92).

Van Engen (1991:93) develops his theological view by stating that the "koinonia fellowship itself embodies a proclamation of the lordship of Jesus of Nazareth". It is the lordship of Christ that propels the Church "outward in its proclamation of the gospel to the world". God's witnessing people find purpose in their existence as the kerygmatic fellowship of disciples who confess that Jesus is Lord. This confession "necessarily involves movement outward toward the world as the arena and recipient of the Church's kerygmatic proclamation" (Van Engen 1991:94).

Scripture makes it clear that "loving koinonia fellowship, a communal life, a kerygmatic proclamation that Jesus is Lord, a sharing with those in need through a loving diaconal ministry all brought about marturia - as God's missionary people witnesses to the fact that Jesus is alive and that he is the Head of the body, the Church, through loving koinonia fellowship, through confession that Jesus Is Lord, and through actions of diaconal service" (Van Engen 1991:98).

The comprehensive understanding of witness (mission) becomes most prominent in the Old Testament while God's people are in exile and experiencing suffering and affliction - so it is in the New Testament. It reaches a climax in the suffering of the Son of Man, especially on Golgotha, where he gave his life as ransom for many (Mk 10.45). What appeared to be defeat and disaster was, in reality, God's road to victory. Therefore the suffering servant of Isaiah 53 was, since the earliest times, regarded as the archetype of Jesus. This perspective accentuates that Jesus became the true personification of mission, not through his preaching and miracles, but through his suffering and death (Bosch 1980:72). Max Warren underlines this view through his beautiful statement that mission is not an ethical command, but a Person: "Jesus... the Great Commission" (in Bosch 1979:71).

For the young New Testament Church it was natural to share in and identify with the suffering of their Lord. In Paul's second letter to the Corinthian Church, he rejects a perspective of mission that is clad in success and triumph. Paul himself is the example of the captive apostle (2 Cor 2:14) who glories in weakness (2 Cor 12:9). "In fact, weakness (astheneia), affliction (thlipsis) and suffering (lype) are key concepts in this letter in which Paul defends his apostleship against "those superlative apostles" (2 Cor 11:5; 12:11) who recommended themselves to the Corinthians. Unlike them he has this treasure in an earthen vessel ( 2 Cor 4:7) a fact to which his suffering testifies abundantly (2 Cor 6:4-10; 11:23-28). Moreover, suffering and affliction are normal experiences in the apostle's life, but for those who can only think in success terms, they remain a skandalon - a stumbling-block" (Bosch 1980:72). Paul's epistle to the Corinthians clearly and indisputably integrates witness 
with the Cross. And then not only the cross of Calvary but also the cross of the apostles and every witness that follows in their steps through the ages.

When Jesus uses the metaphors of salt, light and yeast there is a strong implication of the crossing of borders, entering into uncharted waters. Bosch refers to the insight of Elton Trueblood (in Bosch 1980:73) who claims that "the most surprising thing" about salt, light and yeast is the fact that they are "frustrated" in their true function whenever they are saved or not being used. This happens because the "essence of each is that it is radically expendable." The weakness of the witness is accentuated by this insight and it underlines the view that the "people who are to be won and saved should, so to speak, always be able to crucify the witness of the gospel." This leads to the paradigm of the "Church for others" (Bosch 1980:73).

\section{Affirming a Normative Framework from a comprehensive Biblical understanding of witness}

It is possible to construct a broad framework within which the Biblical meaning of witness can be developed. It is clear that witness can, according to this approach, be divided into the:

- $\quad$ objective (why; reason for);

- $\quad$ agent (who; a person with personal experience or knowledge);

- content (what);

- transfer (how); and

- context (situation, where).

This semantic breakdown of the Biblical concept of witness can be illustrated as follows and forms the basis for the unfolding model.

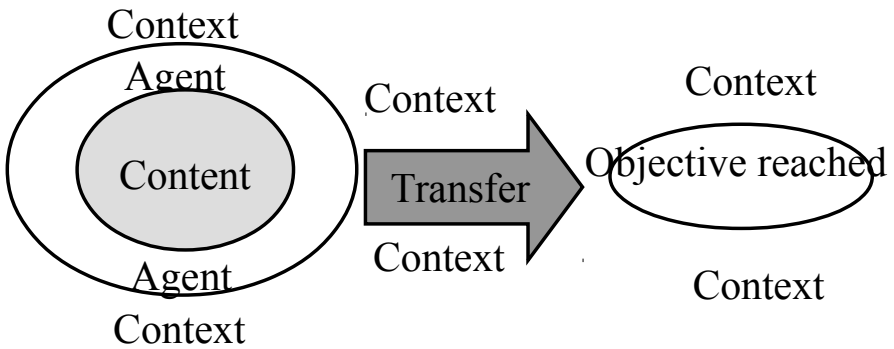

A semantic breakdown of the Biblical concept of witness

\section{Objective of witness}

Although witness in the context of world evangelisation has a content of proclaiming the Good News in such a way that every person on earth has the opportunity to hear it, there is another, more fundamental, point of departure. 
That is for all the people of the earth to become worshippers of God. Though $\mathrm{He}$ is not willing that any should perish (2 $\mathrm{Pe} 3: 9)$, He is more concerned that the people of the earth recognize who He is and worship Him (Reesor 2000). This view is strongly supported by John Piper's well-known statement that "mission is not the ultimate goal of the Church, worship is. Mission exists because worship doesn't" (Piper 1993:11). Witness follows after a desire to see God glorified throughout the earth. The people of the earth cannot worship Him if they don't know, and they cannot know if they cannot hear, and they cannot hear if we do not tell them! (Reesor 2000).

It would be incomplete to discuss the objective of witness without referring to the Kingdom of God as well. John Paul II has spoken of proclamation - explicitly of the Lordship of Jesus and of his vision of the reign of God - as "the permanent priority" of mission. The task of evangelisation would be empty, said Paul VI, without proclaiming "the name, the teaching, the life, the promises, the Kingdom and the mystery of Jesus of Nazareth, the Son of God" (Bevans 2003:50-53).

\section{Agent of witness}

\section{Missio Dei}

When we develop a Biblical paradigm of witness, both Old and New Testaments reveals that God himself is the subject of mission. The marturia, the witness by word and deed, has its ultimate origin not in the witness himself, but in God. Although the witness is still important and part of God's mission, He remains the author (Bosch 1980:74). In this sense we could affirm that God, through his Spirit, is ultimately the Agent of witness!

The designation of the Father as the sender (Jn 20:21) refers not only to his absolute primacy as the owner and initiator of the mission, but also to Jesus as the one uniquely sent by him and totally dependent on him in the execution of "the work." (Okure 1988:278).

\section{Being witnesses}

But God, the supreme Agent of witness, uses His people as witnesses to impact and transform the world. The influence, however, is not limited to those exposed to the witness of believers, but being a witness to the world changes the witness. "New dimensions of truth and new depths of discipleship" will be discovered. And this does not happen when witnesses act from a "position of strength", but when they allow the Holy Spirit to accomplish his powerful work through the witness. "Witness, marturia, means the way of the Cross" (Bosch 1980:205). Witness also means to live within the reality of the risen Lord. The consistent teaching of the New Testament conveys the reality that "the risen Jesus was manifested to those whom God chose - not for themselves, but to be witnesses to all" (Newbigin 1978: 35). 
Christ's Great Commission calls believers to witness as the Holy Spirit leads them to others as they meet them. No matter how sophisticated our methods and media, there is overwhelming evidence that people come to Christ initially and grow in their faith through face-to-face witness and personal involvement (Engel 2000: 100).

Craig describes Christian witness as a duty and a delight. Understanding this perspective the believer should be aware of the "ineffectiveness of isolation" Through this statement he also accentuates the importance of the individual being part of "a great cloud of fellow-witnesses. Few can sustain a sense of fellowship with a world-wide community unless that fellowship is embodied in local, accessible, realisable, neighbourly communities within the great community" (Craig 1946:126).

Craig also emphasises that personal witness will be negatively impacted if the believer does not fit into a local ecclesiae because "no Christian will ever grow to full stature till he finds himself at home in the flock which follows the Good Shepherd" (Craig 1946:127).

Witness should be considered "not only of the Church ecumenical, with its massive corporate impact upon the world; nor only in terms of the individual; but in terms of parish and congregation." The local Church is the organism which creates the reality of fellowship and also helps to carry the witness of its members to the everyday life around them (Craig 1946:127).

"The vitality of a living Christian community will express itself naturally in cheerful social activities as well as in uplifting corporate worship." If the Church takes an apologetic, self-consciously, on the defensive stand and fails to be relevant it would be difficult to visualise any witnessing impact (Craig 1946:131).

Stott (1990:18) verbalizes his view by saying: "Here then is the living God of the Bible. His concerns are all-embracing - not only the 'sacred' but the 'secular', not only religion but nature, not only his covenant people but all people, not only justification but social justice in every community, not only his gospel but his law. So we must not attempt to narrow down his interests."

\section{Witness and the Holy Spirit}

The Spirit of God precedes, stimulates, initiates and empowers witness so that, as in John 15, it is the Spirit who witnesses first (v.26) and then we the disciples (v.27) (Forster \& Richard 1995:18). Okure (1988:144) points out that there is "a suggestion that the Spirit works in some mysterious ways in the world independently of the disciples: he is their co-witness to Jesus (Jn 15:26-27) and also has the task of convicting the world (or of exposing its wrong ideas) concerning sin, righteousness and judgment (Jn 16:7-11)." The Spirit plays a participatory role in Jesus' mission, firstly because "he himself is the fruit of this mission (Jn 7:39; 16:7a; 20:22) and secondly, because he makes possible the witnessing/harvesting mission of the disciples (Jn 16:12-15)." 
"As we engage in witnessing, we are reminded that our testimony does not stand alone. We know that it is buttressed by the witness of the Scriptures and also by the witness of the Holy Spirit. Unless the Spirit convinces people of their need of Christ, our witness will not bear fruit. But, filled with the Spirit, we can speak the word of God with boldness and expect God to work through our witness for his honour and glory" (Trites 1983:142).

\section{The Christian ambassador and witness}

One of the functions of the Christian ambassador is witnessing. "We are therefore Christ's ambassadors, as though God were making his appeal through us. We implore you on Christ's behalf: Be reconciled to God" (2 Cor 5:20). "Pray also for me, that whenever I open my mouth, words may be given me so that I will fearlessly make known the mystery of the gospel, for which I am an ambassador in chains. Pray that I may declare it fearlessly as I should" (Eph 6:19-20).

The principle of witnessing for Christ is that you do it in your own environment (Doud 1997). For that every believer must be prepared. This is where discipleship and catechetical mission becomes relevant (Arias \& Johnson 1992:19). Preparation means flexibility and the ability to use God's Word in witnessing. Knowledge of the basic orthodoxy that will come to life through vibrant orthopraxy.

\section{Laity and formal witness}

Deep-rooted perceptions in many Christian circles reinforce the perspective that laity needs not to be involved in witness. In theological circles, however, it is widely recognised that the laity has a part to play in the formal and direct witness of the Church, in teaching and preaching. A great deal of the religious instruction of the young has always been in the hands of lay men and women and this can hardly be described as an easy or unimportant side of Christian witness. It is true however, that Church members lose interest and involvement tarnishes when leaders fail to "give them a job to do" (Craig 1946:151).

David Lim (2003) points out in the Journal for Asian Mission that lay people will many times be more effective witnesses than clergy-types, because they will have greater credibility, better role modelling ( 2 Th 3:6-10) and more conceptualised witness in society.

Kenneth Strachan (in Telford 1998:147) observes that "every Christian, regardless of his position, is faced with a mission that does not permit him to hide inside sheltering walls, but thrust him out into the world."

There should be preparedness, a readiness in each believer to witness through word and deed - "and your feet shod with the preparation of the gospel of peace" (Eph 6:15). This exhortation is not aimed at a select few, but at every believer. Stott $(1990: 125)$ underlines the fact that diakonia 
(service) and marturia (witness) can not be separated from each other. Therefor every Christian is called to be both a witness and a servant. Garrison (2004:9) indicates that this insight is strongly imbedded in the modern Church Planting Movement. He refers to examples where new converts in India intentionally witness to unbelievers the moment when they become Christians - for them, being a Christian is being a witness!

\section{Content of witness}

The Christological statement that "our message is Jesus Christ," constitutes an essential affirmation that the Gospel "announces glorious Truth." In Christ "we come face to face with the ultimate reality of the universe," the only reality powerful enough to meet the challenge of secularism and the modern global context. "He himself is the Gospel; the Gospel is the message of the Church to the world" (Flett 2003:17-22).

Kirk (1999:224) links his view to Paul, describing his logic as "impeccable", because it is born out of experience. According to him witness is more than the awakening of some truth which already lies dormant in a person's subconscious. "People need to hear the apostolic word about Christ and be urged to believe and be saved" - for him that is the content of witness.

Good deeds form, according to Paul, a substantial content of the witness of believers. Ridderbos (1975:434) points out that God's people "must be in the forefront of good deeds" Searching for the Biblical content of witness we should note that even more than our words, God use the way we love others with Christ's love to build his Kingdom. For that reason Arn (1988:176) defines witness as "the process by which a Christian communicates God's love." The first Bible most people read would be our lives, long before they ever read the book (Graham 1989:8).

It is fitting to conclude with Newbigin's view on the objective of witness, which opens up a cosmic perspective: witness and mission have to do "with the action of God to bring history to its true end" (Newbigin 1978:35).

\section{Transfer of witness}

A WCC document of 1959 stated, "there is no single way to witness to Jesus Christ. The Church has borne witness in different times and places in different ways. This is important. There are occasions when dynamic action in society is called for; there are others when a word must be spoken; others when the behaviour of Christians one to another is the telling witness. On still other occasions the simple presence of a worshipping community or man is the witness. These different dimensions of witness to the one Lord are always a matter of concrete obedience. To take them in isolation from one another is to distort the Gospel" (Bosch 1980:228). 
At the Tambaram conference which took place near Madras, India, it was affirmed that witness cannot only be understood as an oral proclamation of the evangelion. Witness was "to present Christ to the world" in such a way that "the vision and hope of social transformation, justice, freedom and peace will be realized. This does not imply that mission at Tambaram was packaged as the "social gospel".

God's goal is a new heaven and earth ( Rv 21) and we should not be discouraged by the broken reality around us. The doctrine of salvation teaches us that everything can be changed. God's Kingdom "acts both as a ferment and as dynamite in every social system" (Bosch 1980:169).

Joseph Sittler's introduction of the cosmic Christ, which he founded on Col. 1:15-20, lead to the interpretation that God was regarded as being active in every facet of world history. Through this view the contrast between Church and world was in principle abandoned (in Bosch 1980:188). This has fundamental implications for our understanding of the transformational impact of witness.

People will never believe what they hear - however attractive it may sound - if it is blatantly contradicting what they see and experience. All our efforts at renewal in the area of evangelism, catechism, liturgy and so forth, are futile unless something is done about the credibility of the quality of our lives. In fact, the more attractive our verbal proclamation sounds, the more flagrant may be the glaring contrast between this message and the regrettable quality of our lives. The Church is frequently an obstacle rather than an aid to the gospel because she allows her life and conduct to obscure her witness and make it impotent (Bosch 1980:229).

This view is strongly supported by a series of in-depth articles published in Time Magazine of June 16, 2003. An article by Jeff Chu, titled O Father where art Thou?, shares the perspective that the so-called Generation $\mathrm{X}$ and Millennium generation are disillusioned by the inconsistency between statements of faith and the lives of Christians. They are simply not impressed by dusty orthodoxy without supporting orthopraxis. In contrast with previous generations they verbalise their perspectives, experiences and views, rebelling against an establishment that fails to practice what they preach.

\section{Leadership and witness}

Spiritual leadership plays a significant role in the empowerment of Christians (agent of witness) and their ability to witness effectively (transfer of witness). Leaders have the responsibility to "at least stimulate" believers to be "active personalities, men and women of alert minds and spiritual initiative" The unkinder critics hint that the clergy like their people passive, being more concerned to tell them what to think than to make them think; 
finding, perhaps, that spoon-feeding is the safest and least laborious, though the least effective form of adult education" (Craig 1946:131).

\section{Context of witness}

Since the term "contextualisation" was first coined in 1972, Missiologists and Third World theologians have deepened our understanding of the new paradigm. Indigenisation of clerical dress or Church architecture or music will not suffice. The very heart of a culture needs to be embraced and transformed by the Gospel. Such radical contextualisation is similar to that of the apostle Paul, who wrote, "To the Jews I became as a Jew, in order to win Jews" (1 Cor 9:20) (Thomas 2005:2-8).

The witness must always communicate on the basis of solidarity with the people for whom it is intended. A silent presence may, in some circumstances, signify authentic solidarity, as when Ezekiel came to the exiles at the river Kebar and sat with them for seven days, dumbfounded (Ezk 3:15). Only genuine solidarity gives credibility to our marturia.

\section{Witness through suffering and affliction}

In Isaiah 40-55, during the time of the Babylonian captivity, the global motif of the Old Testament revelation is most prominent although God's people were politically and socially in a submissive position. Against this background it is extraordinary and remarkable that a global perspective is strongly revealed while they are in exile. In this unlikely situation we find an "extraordinary combination of suffering and missionary involvement" which opens up a Biblical paradigm of witness (Bosch 1980:70).

For the young New Testament Church it was natural to share in and identify with the suffering of their Lord. In Paul's second letter to the Corinthian Church, he rejects a perspective of mission that is clad in success and triumph. Paul himself is the example of the captive apostle (2 Cor 2:14) who glories in weakness (2 Cor 12:9).

\section{Witness and reconciliation}

God's missionary people are to be a reconciled community who witnesses to the possibility of reconciliation in an alienated world. "The work of bringing God's reconciliation to the world is the heart and soul of the Church's witness" (Van Engen 1991:97 - 98).

\section{Witness and social justice}

Ronald Sider (in Bosch 1980:229) makes a cutting statement: "Only if we Biblical Christians throw ourselves into the struggle for social justice for the wretched of the earth so unequivocally that the poor and the oppressed know beyond all question that we will risk all in the struggle against economic and political oppression - only then will Third World theologians be willing to hear our critique of unbiblical definitions of salvation. And 
only then will the oppressed of the earth be able to hear our Good News about the risen Lord Jesus." James Engel (in Bush 2000) put emphasis on the fact that mission brings justice at the same time as it offers mercy.

\section{Establishing a Normative Framework}

The Westminster Catechism (in Online Bible) declares that the chief end of man was "to glorify God and to enjoy Him forever," and John's Gospel forcefully reminds us that we fulfil this duty when we do what our Heavenly Father does, namely glorify the Lord Jesus Christ. According to the Fourth Gospel the Father bears witness to his Son in the Old Testament Scriptures (Jn 5:39) and the works that he empowers his Son to perform (Jn 5:36). The words of Jesus also came not from himself but from the Father who sent him (Jn 7:16; 12:49). Thus Jesus rebukes his contemporaries for refusing to accept the evidence of his words and works (Jn 14: 10-11). "Since the New Testament now preserves these words and works, we may conclude that the Father's testimony to the Son is recorded in the Biblical witness of the Old and New Testaments. This means that all true God-inspired witness must finally point to Christ” (Trites 1983:147).

\section{Influencing Factors}

Having established a normative framework for understanding comprehensive witness, empirical research (Hancke 2005:146) identified the accelerators and decelerators that influence personal witness:

- Church perspective can have a distinct effect on witness. Understanding the Church - its purpose, nature and character forms the basis from which the believer reaches out to others. Without a sound understanding of the Church, Christians fail to understand their role, responsibility and privilege to be God's transformation 'agents' in the world.

- In a similar way the believer's world perspective can have a significant influence on witness. A limited world-view will seldom support a holistic perspective of witness.

- Understanding Church membership can have an effect on witness. Having a sound Biblical perspective will help believers to understand their role and purpose as members of the body of Christ. A flawed understanding will have the contrarily effect.

- Church leadership play a major role in the ability or inability of members to live a life of dynamic witness. If Church leadership does not understand, accept and drive the mission involvement of the local Church - a noticeable impact is hardly possible. Leadership has the biggest influence on the Church - therefore the continuing Biblical emphasis on the responsibility of the leaders. 
- The approach to doctrine can play a fundamental influencing role. If sound doctrine is seen as the complete content of a believer's faith and the "living" of that doctrine does not play a role - then doctrine, however sound, can have a crippling effect on the witnessing attitude of a Christian. The opposite is true where sound doctrine forms the "launch pad" for dynamic practical witness. Conflict between Christian doctrine and way of life can have devastating effects on witness. The Bible records numerous examples in the Old as well as New Testament. Such discrepancies can be considered as hypocrisy and apostasy.

- The centrality of God's Kingdom and the ability to understand and interpret this truth has a major influence on witness. The Church is a co-partner with God in the process of affecting the Kingdom of God by proclaiming the Gospel of the Kingdom of light in the midst of the Kingdom of darkness. Throughout the Gospels the central aspect of the teaching of Jesus is that concerning the Kingdom of God.

- Situations of suffering and affliction have an effect on witness. Historical records indicate that in such situations witness flourishes. This affirms the principle that witness materializes through more than words - also through suffering.

- Not to take advantage of the opportunity to intentionally witness qualifies the Christian as a "silent witness." As in Biblical times this means that the witness has "nothing to say and that the case goes to the opponent."

- Effective witness asks for a balanced and sensitive spirituality through which the Church "seeks the mind and the will of God." The Church is not just confessing verbally, but is also living out its faith that Jesus, as the Head of His Church, is practically leading, directing and equipping them to effectively and uniquely impact creation. The missional Church understands, accepts and encounters God's unique calling and purpose. The local Church accepts the God-given variety of spirituality. This variety, wisely accepted and integrated into Church-life creates the spiritual environment in which the multi-faceted blessing of the gifts of the Holy Spirit are optimally utilised to build up the Body and to impact creation.

- The factors influencing witness can be ultimately be illustrated as follows:

\section{Influencing Factors}

Concluding our understanding of witness and those influencing factors which finally give rise to Factor Beta, it must be re-affirmed that a withdrawal from witness is withdrawal from grace and not just from duty. 
God uses the individual and corporate witness of His people to bring about a transforming effect on communities, nations and the world.

\section{A model to enlarge missional involvement of the local church}

While the normative process lead to an understanding of the ideal, the empirical process gave an indication of reality. Comparing these results helped to identify a gap - which I call the Beta Gap. The Beta Gap indicates the difference between the norm (ideal) and reality and formed the basis for the development of a transformational model, which will have strategic value for the local Church. Through the application of the model the negative influence of Factor Beta should be combated with the consequence that a more holistic and collective approach, towards being a missional Church, should be possible.

To prevent misunderstanding the word martus is used in the following model for the witness (agent) and marturia for witness (content).
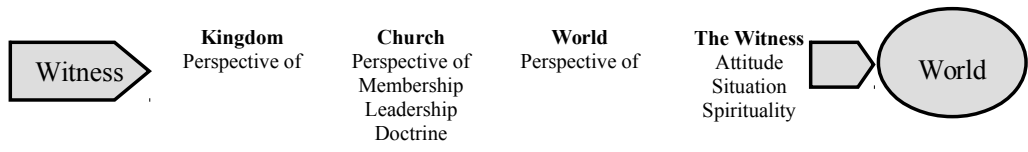

A diagnostic model based on a holistic view of Witness

This model indicates how witness starts with God and how it flows through His people (martus). It realises as marturia through the Church revealing the Saviour to a world desperately in need of Good News. Arrows indicate this 'flow', but the model also points out how the Church is being part of a context and that the marturia flows to a world finding expression within a certain context. This context is formed through worldviews, paradigms, traditions, culture, socio-economic and political realities and can even be drastically influenced by suffering, affliction and persecution. In the final instance the marturia is directed at the world in need. The transition from Church to context in the model is coloured in a way to indicate that there is not a clear boundary of distinction between Church and context. The Church is influenced by the context, while it also forms part of the context and as such conversely influences the context.

The realities, or perceived realities, created by the Church, context and the world are not static, impotent 'filters' or 'receivers' of witness. They again play a fundamental role in continually forming and transforming the insights and lifestyle of the witness. It can be illustrated in the following way: 


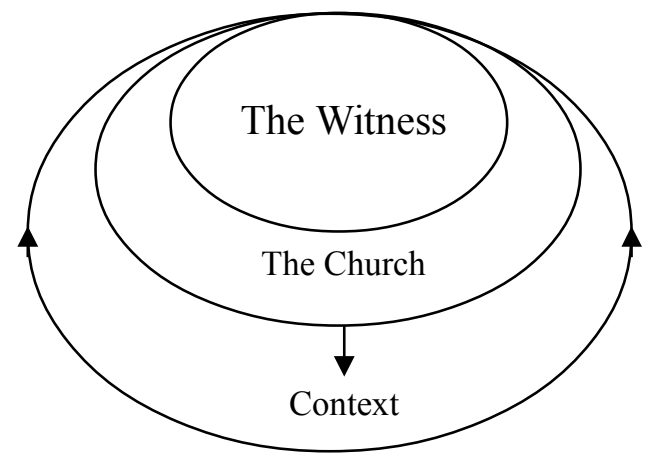

The World

Illustrating the mutual effects of witness, Church, context and world

\section{Strategies to overcome Factor Beta}

Since now there is clarity about those key factors acting as accelerators or decelerators to influence personal and corporate witness, the major focus should be to address these factors in order to lessen the effect of Factor Beta.

Against the background of the previous perspectives it is clear that the subsequent remedial approach can fundamentally address the factors leading to the Beta Gap. The following figure illustrates a simple overlay model. If it were superimposed over the diagnostic model, it would be clear which factors should be addressed by which remedial suggestion.

\section{Discipleship}

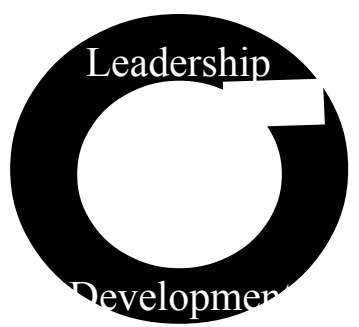

A remedial model to address Factor Beta

The remedial model suggests that two strategies could be instrumental to ensure that greater involvement, outreach and life-changing witness will, in a growing sense, become part of personal and corporate Christianity. 


\section{Discipleship}

The overlay model indicates that discipleship can fulfil a significant role to address the decelerators of witness. No wonder that many theologians see discipleship as an over-arching theme accentuated by Jesus in the gospel of Matthew. In this gospel, which so strongly conveys the Kingdom perspective, Jesus teaches that the Kingdom is all about following, about living and even about dying. He underlines that becoming a disciple involves changed priorities and an altered worldview.

\section{Leadership development}

Leadership development is the other strategy that can have a phenomenal effect on Factor Beta. It is the leadership of the Church who takes initiative and responsibility to equip believers to become witnessing disciples. Without dynamic, visionary leadership the Church and its members will gradually experience the creeping, terminal effects of Factor Beta. There are tragic examples where "much of the predominant leadership has distanced itself from New Testament models that it is no exaggeration to say that the pastoral function is that which has deteriorated most in recent decades" (Yamamori 2004:227). There are however leaders who have a clear vision of the One who had called them, and developed an approach that is serious, profound, and responsible, and for whom the most important thing is to be servant leaders.

Sound Biblical leadership development will address the remainder of the key influencing factors. A previous study (Hancke, 2001) exclusively focuses on this aspect of the missional Church. Dynamic missional leadership will support believers to cope with the context in which they are called to be witnesses (note that part of the context factor can be addressed by discipleship). Pro-active leadership will create the necessary opportunities and structures through which Church members can become God's transformational agents in their community and in the world.

\section{Closing Remarks}

It was not the intention of this research to focus in depth on the accelerators, decelerators and remedial strategies but rather to discover and identify the strategic reasons for the reality of Factor Beta. Resulting from that the diagnostic and remedial models will provide strategic direction and support the Church to combat Factor Beta and to stimulate a growing personal and corporate witness, which will lead to the development of the critical mass that is needed for a global acceleration in becoming missional Christians and missional Churches.

Tennant (2005:171) refers to Philip Jenkins who has highlighted in his book The Next Christendom: The Coming of Global Christianity, the vigorous growth of Christianity in the non-Western world. Jenkins predicts that 
"if current trends continue, six countries in the world will have 100 million Christians by the year 2050, but only one of the six (the United States) will be located in the industrialized West. Within the next twenty-five years there will be more Christians in Africa than in either Europe or North America. Christianity is also exploding in the heartlands of Hinduism, Buddhism, and Chinese religions. In these contexts the very word 'Christian' carries strong connotations of Western culture or foreignness. For many, the words 'Christian' and 'Church' call to mind Western imperialism or colonialism or worse. In short, the phrase 'Christian Church' can carry very negative cultural connotations, whereas the name 'Christ' may not. This reality has caused many to rethink the very nature of the Church as it has been." Witness is not a philosophy - people do not live and function within the realm of a philosophy. The Church exists in reality. To be called as witnesses is not a vague philosophy - it is God using His people in this broken reality to make a difference - to expose the Kingdom of God in action. If the results of this research eventually lead to a philosophical model, little would have been accomplished. It would make little or no contribution to help the Church to be God's transformational agent in the world. Such results will be superficial and of doubtful value.

It is possible that the application of the insights acquired from this research can have a transformational effect on personal and eventually corporate witness. Factor Beta must be combated by developing a critical mass through the addition of more effective witnesses. This can eventually lead to a new movement of enthusiastic believers reaching out in order for the whole Church to take the whole gospel to the whole world.

\section{Bibliography}

Arias, Mortimer, \& Johnson, Alan 1992. The Great Commission: Biblical models for Evangelism. Nashville: Abingdon Press.

Arn, W 1988. The Master's Plan for making Disciples: How every Christian can be an effective witness through an enabling Church. Pasadena, California: Church Growth Press.

Bevans, Stephen B 2003. Unravelling a "Complex reality": Six elements of Mission. International Bulletin of Missionary Research 27(2), $50-53$.

Bosch, David J 1979. Heil vir die Wêreld. Pretoria: NG Kerk Boekhandel Transvaal.

Bosch, David J 1980. Witness to the World: The Christian mission in Theological perspective. Atlanta: John Knox Press. 
Bush, Luis K (2000) Global Mission 2000: Where are we now and where do we go from here with the Great Commission? Presentation for one-day seminars in South Africa.

Craig, A C, \& Martin, Hugh 1946. Christian Witness in the Post-war World; An ecumenical symposium. London: S.C.M. Press.

Doud, Warren 1997. Grace Notes: Christian way of life [Internet] Available from $<$ http://www.realtime.net/wdoud/ $>$

Engel, James F, \& Dyrness, William 2000. Changing the Mind of Missions: Where have we gone wrong? Downers Grove, IL: InterVarsity Press.

Engelsviken, Tormod. (2005) Missio Dei: The understanding and misunderstanding of a theological concept in European churches and missiology Available < http://imissional.org/wp-content/ uploads/2010/07/Missio-Dei-Understanding-and-Misunderstanding 1.pdf $>$ [Accessed 18 May 2014].

Flett, John 2003. From Jerusalem to Oxford: Mission as the foundation and goal of Ecumenical Social thought. International Bulletin of Missionary Research i, 17-22.

Forster, Roger, \& Richard, John 1995. Churches that Obey: Taking the Great Commission seriously. Carlisle: OM Publishing.

Garrison, David 2004. Church Planting Movements. Mission Frontiers, 00.04.36-CPM.

Graham, Billy 1989. You His Witness. Leicester: Frameworks,

Hancke, F J v H. (2001) The common critical success factors determining the mission impact of the local Church: An analytical study. MA thesis, University of the Free State.

Hancke, F J v H. (2005) Factors influencing comprehensive personal witness and enlarging missional involvement in the local church. $\mathrm{PhD}$ dissertation, University of the Free State.

Kirk, J A 1999. What is Mission? Theological explorations. London: Darton, Longman \& Todd.

Kritzinger, J J. (2005) Interview 23 June 2005: Clarens, South Africa

Lim, David S. (2003) Mobilizing the Local Church in Evangelism and Mission [Internet] Available < http://www.apts.edu/jam/6-1/DLim.pdf\#search='Mobilizing\%20the\%20Local\%20Church\%20in $\% 20$ Evangelism $\% 20$ and $\% 20$ Mission' > [Accessed 28. 10. 2005]. 
Newbigin, Lesslie 1978. The open Secret: Sketches for a missionary theology. Grand Rapids, Mich.: Eerdmans.

Okure, Teresa 1988. The Johannine approach to Mission: A contextual study of John 4:1-42. Tübingen: J.C.B. Mohr (Paul Siebeck).

Piper, John 1993. Let the Nations be glad: The supremacy of God in missions. Grand Rapids: Baker Books Michigan.

Reesor, Larry. (2000) A Fresh Perspective on Mobilizing the Church [Internet] Available from

$<$ http://www.missionfrontiers.org/2000/01/reesor.htm>

Ridderbos, Herman 1975. Paul: An outline of his Theology. Grand Rapids: Wm B. Eerdmans Publishing Company.

Stott, John R W 1990. Issues facing Christians Today: New perspectives on social and moral dilemmas. London: Marshall Pickering.

Telford, Tom 1998. Missions in the 21st century. Wheaton, Illinois: Harold Shaw Publishers.

Tennent, Timothy C 2005. The Challenge of Churchless Christianity 2005: An Evangelical Assessment. International Bulletin for Missionary Research iv, 171-177.

Thomas, Norman E 2005. Radical Mission in a Post-9/11 World: Creative dissonances. International Bulletin of Missionary Research 29(1), $2-8$.

Trites, Allison A 1977. The New Testament concept of Witness. Cambridge: University Press.

Trites, Allison A 1983. New Testament Witness in today's World. Valley Forge, Pa.: Judson Press.

Van Engen, Charles 1991. God's Missionary People: Rethinking the purpose of the local Church. Grand Rapids, Michigan: Baker Books.

Van Gelder, Craig., Zscheile, Dwight J. and Roxburgh, Alan 2011. Missional Church in Perspective, The (The Missional Network): Mapping Trends and Shaping the Conversation. Grand Rapids, Baker Academic.

Yamamori, Tetsunao, \& Padilla, C René (ed) 2004. The local Church, Agent of Transformation: An ecclesiology of integral Mission. Buenos Aires: Kairos Ediciones 